\title{
Correction to: 2D morphometric analysis of Arabidopsis thaliana nuclei reveals characteristic profiles of different cell types and accessions
}

\author{
Penka Pavlova • Martijn van Zanten (1) \\ Basten L. Snoek (1) - Hans de Jong (D). \\ Paul Fransz
}

Published online: 28 December 2021

(C) Springer Nature B.V. 2021

\section{Correction to: Chromosome Res https://doi.org/10.1007/s10577-021-09673-2}

The original version of this article unfortunately contained a mistake.

The Tables 1 and 2 were published erroneously.

The corrected Tables 1 and 2 were shown in the next page.

The original article can be found online at https://doi.org/ 10.1007/s10577-021-09673-2.

P. Pavlova $\cdot$ H. de Jong

Laboratory of Genetics, Wageningen University

and Research, Droevendaalsesteeg 1,

6708 PB Wageningen, The Netherlands

M. van Zanten

Molecular Plant Physiology, Institute of Environmental

Biology, Utrecht University, Padualaan 8,

3584 CH Utrecht, The Netherlands

B. L. Snoek

Theoretical Biology and Bioinformatics, Institute

of Biodynamics and Biocomplexity, Utrecht University,

Padualaan 8, 3584 CH Utrecht, The Netherlands

P. Fransz $(\bowtie)$

Swammerdam Institute for Life Sciences, University of Amsterdam, Science Park 904, 1098 XH Amsterdam, The Netherlands

e-mail: P.F.Fransz@uva.nl
The publisher sincerely apologizes for this error and any inconvenience caused to the authors and readers of the journal.

The original article has been corrected.

Publisher's note Springer Nature remains neutral with regard to jurisdictional claims in published maps and institutional affiliations. 
Table.1 Morphometric parameters used for chromatin profiling together with their Biological equivalent,Description, and Mathematical formula.

\begin{tabular}{|c|c|c|c|c|c|}
\hline & Biological feature & Parameter (trait) & Description & Formula & Unit \\
\hline \multirow{4}{*}{ 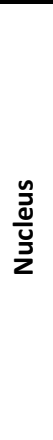 } & Size & Area & Sum of pixels within area of $\mathrm{Nu}$ & $\sum$ pixels & pixel \\
\hline & DNA density & Intensity mean & $\begin{array}{l}\text { Average fluorescent intensity of } \\
\text { DAPI stain of } \mathrm{Nu}\end{array}$ & $\begin{array}{l}\Sigma \text { intensity / number } \\
\text { pixels }\end{array}$ & \\
\hline & $\begin{array}{l}\text { Variation in DNA } \\
\text { density }\end{array}$ & Heterogeneity & $\begin{array}{l}\text { Fraction of pixels that deviate } \\
\text { more than } 10 \% \text { from the aver- } \\
\text { aged intensity mean of } \mathrm{Nu}\end{array}$ & & \\
\hline & DNA content & Intensity sum & $\begin{array}{l}\text { Sum of fluorescent intensity of } \\
\text { DAPI stain of } \mathrm{Nu}\end{array}$ & & \\
\hline \multirow{6}{*}{ 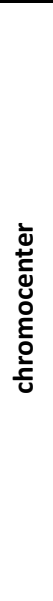 } & Total size & Total area & Sum of areas of all CCs in $\mathrm{Nu}$ & $\Sigma$ pixels $\mathrm{x}$ number $C C$ & pixel \\
\hline & Average size & Area average & Average area of individual CCS & $\Sigma$ pixels / number CC & pixel \\
\hline & DNA density & Intensity (mean) & $\begin{array}{l}\text { Average fluorescent intensity of } \\
\text { DAPI stain of individual CCs in } \\
\mathrm{Nu}\end{array}$ & $\begin{array}{l}\Sigma \text { intensity / number } \\
\text { pixels }\end{array}$ & \\
\hline & DNA content & Intensity (sum) & $\begin{array}{l}\text { Sum of fluorescent intensity of } \\
\text { DAPI stain of all CCs in } \mathrm{Nu}\end{array}$ & $\Sigma$ intensity & \\
\hline & $\begin{array}{l}\text { Heterochromatin } \\
\text { content in } \mathrm{Nu}\end{array}$ & $\begin{array}{l}\text { Relative Hetero- } \\
\text { chromatin Fraction } \\
\text { (RHF) }\end{array}$ & $\begin{array}{l}\text { Fraction of DNA content of } C C S \\
\text { per } \mathrm{Nu}\end{array}$ & $\begin{array}{l}\Sigma \text { (area } C C x \text { intensity } \\
\text { mean } C C) /(\text { area } N u x \\
\text { intensity mean } N u \text { ) }\end{array}$ & \\
\hline & Number CCs & $\# C C$ & Sum of all CCs in $\mathrm{Nu}$ & $\Sigma C C S$ & \\
\hline \multirow{3}{*}{ 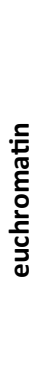 } & Size & Area & Area of $E u$ & $\begin{array}{l}\Sigma \text { pixels } N u-\Sigma \text { pixels } \\
C C\end{array}$ & pixel \\
\hline & DNA density & Intensity (mean) & $\begin{array}{l}\text { Average fluorescent intensity of } \\
\text { DAPI stain of } E u\end{array}$ & $\begin{array}{l}{[\Sigma \text { intensity (sum) } \mathrm{Nu}-} \\
\Sigma \text { intensity (sum) } \mathrm{CC}] / \\
\text { area } E u\end{array}$ & \\
\hline & DNA content & Intensity (sum) & $\begin{array}{l}\text { Sum of fluorescent intensity of } \\
\text { DAPI stain of Eu }\end{array}$ & $\begin{array}{l}\Sigma \text { intensity (sum) } \mathrm{Nu}-\Sigma \\
\text { intensity (sum) } \mathrm{CC}\end{array}$ & \\
\hline
\end{tabular}

Note: Chromocenter $(\mathrm{CC})$ is used in the meaning of a microscopically visual heterochromatin body in the interphase nucleus. DNA density as a biological feature is used as equivalent to DNA concentration. $\mathrm{Nu}=$ nucleus, $\mathrm{Eu}=$ euchromatin 
Table.2 Fraction of transposable elements in heterochromatin and euchromatin

\section{cell types}

\section{accessions}

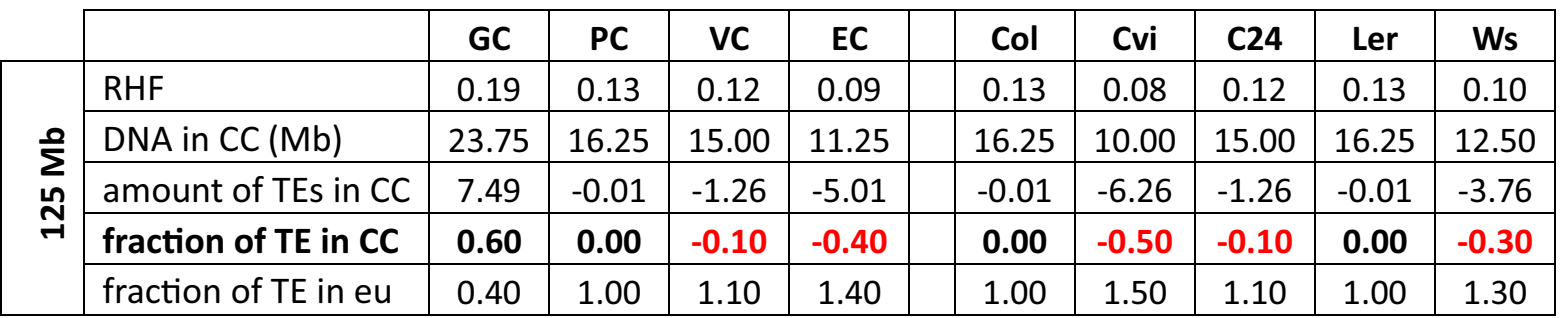

\begin{tabular}{|c|c|c|c|c|c|c|c|c|c|c|}
\hline & & GC & PC & VC & EC & Col & Cvi & C24 & Ler & Ws \\
\hline \multirow{5}{*}{$\begin{array}{l}\stackrel{0}{\Sigma} \\
\text { Ln } \\
\text { L }\end{array}$} & RHF & 0.19 & 0.13 & 0.12 & 0.09 & 0.13 & 0.08 & 0.12 & 0.13 & 0.10 \\
\hline & DNA in $\mathrm{CC}(\mathrm{Mb})$ & 23.75 & 16.25 & 15.00 & 11.25 & 16.25 & 10.00 & 15.00 & 16.25 & 12.50 \\
\hline & amount of TEs in CC & 7.49 & -0.01 & -1.26 & -5.01 & -0.01 & -6.26 & -1.26 & -0.01 & -3.76 \\
\hline & fraction of TE in CC & 0.60 & 0.00 & -0.10 & -0.40 & 0.00 & -0.50 & -0.10 & 0.00 & -0.30 \\
\hline & fraction of TE in eu & 0.40 & 1.00 & 1.10 & 1.40 & 1.00 & 1.50 & 1.10 & 1.00 & 1.30 \\
\hline
\end{tabular}

\begin{tabular}{|c|c|c|c|c|c|c|c|c|c|c|}
\hline & & GC & PC & VC & EC & Col & Cvi & $\mathrm{C} 24$ & Ler & Ws \\
\hline \multirow{5}{*}{$\begin{array}{l}\text { 을 } \\
\text { न्- }\end{array}$} & RHF & 0.19 & 0.13 & 0.12 & 0.09 & 0.13 & 0.08 & 0.12 & 0.13 & 0.10 \\
\hline & DNA in CC (Mb) & 36.29 & 24.83 & 22.92 & 17.19 & 24.83 & 15.28 & 22.92 & 24.83 & 19.10 \\
\hline & amount of TEs in CC & 20.03 & 8.57 & 6.66 & 0.93 & 8.57 & -0.98 & 6.66 & 8.57 & 2.84 \\
\hline & fraction of TE in CC & 1.05 & 0.45 & 0.35 & 0.05 & 0.45 & -0.05 & 0.35 & 0.45 & 0.15 \\
\hline & fraction of TE in eu & -0.05 & 0.55 & 0.65 & 0.95 & 0.55 & 1.05 & 0.65 & 0.55 & 0.85 \\
\hline
\end{tabular}

\begin{tabular}{|c|l|c|c|c|c|c|c|c|c|c|c|}
\cline { 2 - 11 } \multicolumn{1}{c|}{} & GC & PC & VC & EC & Col & Cvi & C24 & Ler & Ws \\
\hline \multirow{3}{*}{$\underset{\mathbf{\Sigma}}{\boldsymbol{\Sigma}}$} & RHF & 0.19 & 0.13 & 0.12 & 0.09 & 0.13 & 0.08 & 0.12 & 0.13 & 0.10 \\
\cline { 2 - 11 } & DNA in CC (Mb) & 40.09 & 27.43 & 25.32 & 18.99 & 27.43 & 16.88 & 25.32 & 27.43 & 21.10 \\
\cline { 2 - 11 } & amount of TEs in CC & 23.83 & 11.17 & 9.06 & 2.73 & 11.17 & 0.62 & 9.06 & 11.17 & 4.84 \\
\cline { 2 - 11 } & fraction of TE in CC & $\mathbf{1 . 1 3}$ & $\mathbf{0 . 5 3}$ & $\mathbf{0 . 4 3}$ & $\mathbf{0 . 1 3}$ & $\mathbf{0 . 5 3}$ & $\mathbf{0 . 0 3}$ & $\mathbf{0 . 4 3}$ & $\mathbf{0 . 5 3}$ & $\mathbf{0 . 2 3}$ \\
\cline { 2 - 11 } & fraction of TE in eu & -0.13 & 0.47 & 0.57 & 0.87 & 0.47 & 0.97 & 0.57 & 0.47 & 0.77 \\
\hline
\end{tabular}

$\mathrm{CC}=$ chromocenter, $\mathrm{TE}=$ transposon element, eu=euchromatin, $\mathrm{GC}=$ guard cell, $\mathrm{PC}=$ pavement/parenchyma cell, $\mathrm{VC}=\mathrm{vascular}$ cell. $\mathrm{EC}=$ endopolyploid cells, $\mathrm{Mb}=$ megabasepairs

The negative values for the fraction of TEs in CC (red) suggests that in addition to all TEs also a fraction of the major tandem repeats is in euchromatin. The negative values for the fraction of TEs in euchromatin (i.e., GC values in $191 \mathrm{Mb}$ and $211 \mathrm{Mb}$ ) suggest more DNA in the CCs than the sum of tandem repeats and TEs. This implies that genes are also present in CCs. 